\title{
EVALUATION OF SOME SUGAR BEET VARIETIES AS AFFECTED BY HARVESTING DATES UNDER NEWLY RECLAIMED SOIL
}

\author{
SHALABY, N.M.E., A.M.H. OSMAN AND A.H.S.A. EL-LABBODY \\ Sugar Crops Res. Inst., ARC, Giza
}

(Manuscript received 13 September 2010 )

\begin{abstract}
Two field experiments were carried out during 2008/2009 and 2009/2010 seasons at Kafr El-Hammam village, Sharkia Governorate to study the effect of harvesting dates on productivity of some sugar beet varieties. Sugar beet varieties Gazella, Carola and Lola were planted on $1^{\text {st }}$ October in both seasons. Harvesting dates were done at 180, 195 and 210 days from sowing. The experimental design was a split-plot design with four replication, harvesting dates were allocated in the main plots and varieties in the sub-plots. Results showed that: delaying harvesting dates from 180 to 210 days from sowing significantly increased root fresh weight ( $\mathrm{g} /$ plant), sucrose $\%$, as well as root and sugar yield (tons/fed). While, nitrogen\%, sodium\%, potassium $\%$ were decreased significantly in both seasons. Harvesting dates at 195 days from sowing gave the highest values. Sugar beet varieties gave significant increase for root fresh weight ( $\mathrm{g} /$ plant), sucrose $\%$, as well as, root yield and sugar yield (tons/fed) in both seasons. While, sodium $\%$, potassium $\%$ decreased significantly in both seasons. However, root diameter in the $2^{\text {nd }}$ season only. The interaction was significant in both seasons for root fresh weight (g/plant), sucrose\%, root and sugar yield (tons/fed). However, root diameter in the $1^{\text {st }}$ season and sodium and potassium $\%$ in the $2^{\text {nd }}$ season., respectively. In general it can be concluded that harvesting Lola sugar beet variety at 195 days from sowing was the best treatment for maximizing sugar beet productivity in the newly reclaimed soils under the environment of this study.
\end{abstract}

\section{INTRODUCTION}

Egyptian Government imports about 1.10 milion ton of sugar, every year to face the rapid increase of population. Sugar beet plays a prominent role in sugar production, about $37.27 \%$ of the local sugar production, which amounted to 1.61 million ton, is produced from sugar beet, which is considered the second sugar crop after sugar cane. (CCSC, 2010). Many workers found that late harvesting of sugar beet crop increased growth traits, quality\%, yields/fed and decreased impurities i.e. nitrogen $(\mathrm{N})$, sodium $(\mathrm{Na})$ and potassium (K\%), Abou El-Maged et al (2003) in Egypt found significant increase for root length, diameter, root fresh weight/plant, sucrose $\%$, as well as root and sugar yields/fed in both seasons and significant decrease of $\mathrm{Na}, \mathrm{K}$ and N\%. Aly (2006) showed that root diameter, fresh weight/plant, as well as root and sugar yields/fed were positively increased by delaying harvest dates from 170, 
190 to 210 days from sowing. Early harvest date at 170 day from sowing gave the highest mean values of $\mathrm{Na}$ and $\mathrm{K} \%$. Azzazy et al (2007) and El-Sheikh et al (2009) harvested sugar beet varieties at 210 days from sowing showed significant effect on root weight, sucrose $\%$, impurities, i.e. $\mathrm{Na} \%$ and $\mathrm{K} \%$, as well as root and sugar yields/fed, than the other two harvest dates 180 and 195 days from sowing in both seasons. Except root diameter. Mahmoud et al (2008) reported that the max. sucrose $\%$, as well as, root and sugar yields/fed were obtained when increasing harvesting dates from 180 up to 210 days from sowing.

All sugar beet genotypes cultivated in Egypt are imported from foreign countries, so, it is preferable to evaluate them under Egyptian conditions especially under newly reclaimed soil and different harvesting dates to select the best suited ones. The differences between varieties in gene make up expression may be throwing some light on the relative importance of studying varieties behavior through the growing season. Osman et al (2003) in Egypt, showed that Kawemira variety was superior in sucrose\%, root and sugar yields/fed compared to sugar beet varieties Top, Lola and Pleno. Aly (2006), Azzazy et al (2007) and El-Sheikh et al (2009) showed that the examined sugar beet varieties varied significantly for root fresh weight/plant, as well as, root and sugar yields/fed, while, root length and diameter, as well as, sucrose\% and purity\% were insignificant differences. Enan et al (2009) in Egypt, showed that sugar beet varieties differed significantly in root length, diameter, fresh weight/plant, TSS\% and root yields/fed in both seasons and sugar yield in the $1^{\text {st }}$ season. Farida variety significant increase of total soluble solids $\%$, sucrose $\%$, purity $\%$ and sugar yields/fed, while, it recorded the lowest values for impurities\%, i.e. $\mathrm{N}$, Na and $\mathrm{K} \%$ in both seasons. Simple correlation matrix Dewy and Lu (1959) found that positive linear correlation for components of wheat and seed production. The aim of this study, select the best harvest date to obtain highest yield and quality.

\section{MATERIALS AND METHODS}

Two field experiments were carried out during 2008/2009 and 2009/2010 seasons at Kafr El-Hammam village, Sharkia Governorate to study the effect of harvesting date on productivity of some sugar beet varieties. Sugar beet varieties Gazella, Carola and Lola were planted on $1^{\text {st }}$ October in both seasons. Harvesting dates were done at 180 , 195 and 210 days from sowing. Some chemical and physical properties of the experimental soil were estimated according to Page 1982 in Table 1. Mean of temperature and relative humidity percentage are presented in Table 2. 
Table 1.Some physical and Chemical analysis of the experimental soil*

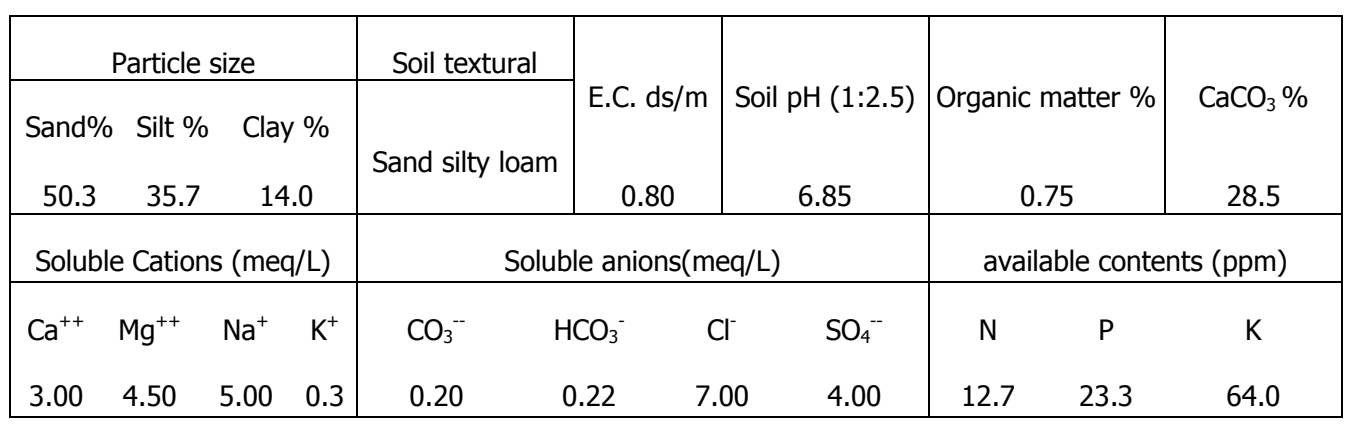

*Each value represents the mean of 4 samples at 2008/200 and 2009/2010.

Table 2 . The temperature and relative humidity percentage

\begin{tabular}{|c|c|c|c|c|c|c|c|c|c|c|c|c|}
\hline Year & \multicolumn{6}{|c|}{$2008 / 2009$ season } & \multicolumn{6}{|c|}{ 2009/2010 season } \\
\hline \multirow{2}{*}{ Months } & \multicolumn{3}{|c|}{ Temp. $\left(C^{0}\right)$} & \multicolumn{3}{|c|}{ Rh \% } & \multicolumn{3}{|c|}{ Temp. $\left(\mathrm{C}^{\circ}\right)$} & \multicolumn{3}{|c|}{ Rh \% } \\
\hline & $M x$ & Min & Avr & $M x$ & Min & Avr & $M x$ & Min & Avr & $M x$ & Min & Avr. \\
\hline October & 32.0 & 18.0 & 25.0 & 84 & 30 & 57.0 & 30.8 & 17.3 & 24.1 & 80 & 26 & 53.0 \\
\hline November & 26.0 & 16.0 & 21.0 & 87 & 39 & 61.0 & 27.1 & 12.7 & 19.9 & 79 & 28 & 53.5 \\
\hline December & 21.0 & 11.0 & 16.0 & 79 & 35 & 57.0 & 20.2 & 7.2 & 13.7 & 80 & 35 & 57.5 \\
\hline January & 20.0 & 10.0 & 15.0 & 81 & 34 & 57.5 & 20.1 & 6.6 & 13.3 & 76 & 32 & 54.0 \\
\hline February & 22.0 & 10.0 & 16.0 & 84 & 34 & 59.5 & 20 & 5.9 & 12.9 & 85 & 34 & 59.5 \\
\hline March & 24.0 & 10.0 & 17.0 & 80 & 30 & 55.0 & 24.2 & 8.4 & 16.3 & 77 & 27 & 52.0 \\
\hline April & 28.0 & 12.0 & 20.0 & 79 & 22 & 50.5 & 29.1 & 12 & 20.5 & 75 & 23 & 49.0 \\
\hline
\end{tabular}

Source: Agro-meteorological station, Agric. Res. Center, Giza, Egypt. Temp. = Temperature $\left(\mathrm{C}^{\circ}\right) . \mathrm{Rh} \%=$ Relative humidity \%. Max. $=$ Maximum. Min. $=$ Minimum. Avr. $=$ Average.

The experimental design was a split-plot design with four replications, harvesting dates were allocated in the main plots and varieties in the sub-plots. Each sub plot was $15.60 \mathrm{~m}^{2} / \mathrm{fed}$. Plant density 43077 plants/fed on ridges which consisted of four ridges at $65 \mathrm{~cm}$ width, $6 \mathrm{~m}$ in length and $15 \mathrm{~cm}$ between hills spacing. Nitrogen fertilizer (as ammonium nitrate $33.5 \% \mathrm{~N}$ ) at the rate of $100 \mathrm{~kg} / \mathrm{fed}$ was applied in four equal portions, the first was applied after thinning and 15 days between the others. 
Phosphorus fertilizer (as calcium super phosphate $15.5 \% \quad \mathrm{P}_{2} \mathrm{O}_{5}$ ) at the rate of 45 $\mathrm{kg} / \mathrm{fed}$ was added during land preparation. Potassium fertilizer (as potassium sulfate $48 \% \mathrm{~K}_{2} \mathrm{O}$ ) at the rate of $36 \mathrm{~kg} /$ fed was applied with nitrogen fertilizer. Manual planting was achieved in hills with approximately 3-4 seeds/hill and then plants were thinned at four leaf stage (after 45 days from sowing) to obtain one plant/hill. Other agricultural practices required for growing sugar beet were carried out as usually practiced in the region. The previous crop was Maize in both seasons.

\section{Recorded data:}

At harvest, two guarded ridges of each plot were harvested to determine the following traits:

A. Vegetative traits: 1 . Root dimensions (length and diameter, $\mathrm{cm}$ ) were measured in ten guarded plants. 2. Root fresh weight/plant was weight on fresh weight basis.

B. Quality traits: Samples of twenty roots were taken randomly, send to the laboratory, cleaned with running tap water, dried, each sample was grated separately with grater into cassettes and mixed thoroughly to determined, the quality traits as described in Cooke and Scott (1993).

1. Sucrose\% was estimated in fresh samples of sugar beet roots, polarimeterically on a lead acetate extract of fresh macerated root according to Le Docte (1927).

2. Impurities content, i.e. $\mathrm{a}-\mathrm{N} \%, \mathrm{Na} \%$ and $\mathrm{K} \%$ as milliequivalent $/ 100 \mathrm{~g}$ beet were estimated according to AOAC (2005).

C. Productivity traits: 1 . Root yield (ton/fed): plants of sugar beet from each plot were harvested topped to determine root yield as ton/fed on fresh weight basis.

2. Sugar yield (ton/fed) was calculated using the following equation:

Sugar yield $($ ton $/$ fed $)=$ Root yield $x$ sugar recovery $\%$.

The collected data were statistically analyzed according to Snedecor and Cochran (1981). Treatment means were compared using LSD at 5\% level probability. Also, simple correlation coefficients and linear regression were computed among studied traits according to Steel and Torrie (1980).

\section{RESULTS AND DISCUSSION}

\section{Effect of Harvest dates: I.1. Growth traits:}

The results in Table 3 showed that root fresh weight ( $g /$ plant) was significant increased in both seasons. Harvesting date at 195 days from sowing out yielded the other dates significantly (1200 and $1100 \mathrm{~g} /$ plant) for root fresh weight in both seasons. This result may be due to data in Table 1 were soil textural was sandy silty 
loam and organic matter was low $0.75 \%$. These results are in agreement with Aly (2006) and El-Sheikh et al (2009).

\section{I.2. Juice quality (sucrose $\%$ ) and impurities\% (a-N\%, Na\% and $\mathrm{K} \%$ ):}

Results presented in Table 3 showed that harvesting date at 195 days from sowing significantly affected sucrose $\%$ and impurities $\%$ in both seasons. The highest mean values for sucrose $\%$ were (17 and $16 \%$ ) in the $1^{\text {st }}$ and $2^{\text {nd }}$ seasons. This superiority at sucrose $\%$ may be due to the decreased temperature at this time of harvest Table 2 . While, impurities\%, gave the lowest mean values in the $1^{\text {st }}$ season were 0.99 for a$\mathrm{N} \%, 1.82$ for $\mathrm{Na} \%$ and 4.03 for $\mathrm{K} \%$ resulted from harvesting date of 195 days from sowing. The same respective values in the $2^{\text {nd }}$ season were, 0.71 for a-N\%, 1.42 for $\mathrm{Na} \%$ and 4.83 for K\%., respectively. This result is in agreement with El-Sheikh et al (2009).

\section{I.3. Root and sugar yields (ton/fed).}

Results collected in Table 3 show the effect of harvesting dates on root yield (ton/fed) in 2008/2009 and 2009/2010 seasons. From results it could be seen that root yield was significantly affected by harvesting dates in both seasons. Harvesting date at 195 days from sowing gave (32 and 31 tons/fed) of root yield and sugar yield, 5.44 and 4.96 tons/fed, in both seasons., respectively. This result may be due to increasing growth characters and sucrose $\%$ at this time of harvest compared to values at the other harvesting dates. These results were coincide by Mahmoud et al (2008) and ElSheikh et al (2009).

Table 3. Effect of harvesting dates on roots growth, quality and yields at harvest

\begin{tabular}{|c|c|c|c|c|c|c|c|c|c|}
\hline \multicolumn{10}{|c|}{$2008 / 2009$ season } \\
\hline Characters & \multicolumn{3}{|c|}{ Growth traits } & Quality\% & \multicolumn{2}{|c|}{$\begin{array}{c}\text { Yields } \\
\text { (ton/fed) }\end{array}$} & \multicolumn{3}{|c|}{ Impurities $\%$} \\
\hline $\begin{array}{c}\text { Harvesting } \\
\text { dates }\end{array}$ & RL & $\mathrm{RD}$ & RFW & Sucrose & RY & SY & $\mathrm{a}-\mathrm{N} \%$ & $\mathrm{Na} \%$ & $\mathrm{~K} \%$ \\
\hline 180 & 27.11 & 11.72 & 800 & 13.00 & 27.00 & 3.51 & 1.21 & 2.11 & 5.99 \\
\hline 195 & 31.60 & 15.75 & 1200 & 17.00 & 32.00 & 5.44 & 0.99 & 1.82 & 4.03 \\
\hline 210 & 29.22 & 13.86 & 1000 & 15.00 & 29.00 & 4.35 & 1.13 & 2.00 & 5.09 \\
\hline LSD at $5 \%$ & NS & NS & 0.01 & 0.23 & 0.22 & 0.05 & 0.19 & 0.07 & 0.15 \\
\hline \multicolumn{10}{|c|}{$2009 / 2010$ season } \\
\hline 180 & 28.00 & 12.94 & 700 & 12.00 & 27.00 & 3.24 & 0.96 & 1.72 & 5.83 \\
\hline 195 & 32.00 & 16.64 & 1100 & 16.00 & 31.00 & 4.96 & 0.71 & 1.42 & 4.83 \\
\hline 210 & 30.00 & 14.14 & 900 & 14.00 & 29.00 & 4.06 & 0.87 & 1.55 & 5.00 \\
\hline LSD at $5 \%$ & NS & NS & 0.07 & 0.27 & 0.31 & 0.08 & 0.03 & 0.10 & 0.10 \\
\hline
\end{tabular}

Growth traits, RL and RD (root length and diameter $\mathrm{cm}$ ), RFW: root fresh weight (g/plant). Yields, RY and SY (root and sugar yields/fed). Impurities\% (N: nitrogen, Na: sodium, K: potassium). 


\section{Varietal effects: II.1. Growth traits:}

The obtained results in Table 4 showed that sugar beet varieties insignificant in root length in both seasons. While, root diameter was affected significantly in the $2^{\text {nd }}$ season and gave the highest value $(15 \mathrm{~cm})$. While, root fresh weight was significantly superior to the other varieties in both seasons were it produced (1300 and 1250 $\mathrm{g} /$ plant) obtained from Lola variety. This superior may be due to the genetic structure of this variety. These results were similar to those by Aly (2006) and El-Sheikh et al (2009).

\section{II.2. Juice Quality (sucrose \%) and impurities\% (a-N\%, $\mathrm{Na} \%$ and $\mathrm{K} \%$ ):}

The results presented in Table 4 showed that varieties effects on sucrose\%, sodium $\%$ and potassium $\%$ in both seasons were significant, except, nitrogen $\%$. The highest mean values (17 and 16 for sucrose $\%$ ). This superiority at sucrose $\%$ may be due to the gene structure of Lola sugar beet variety. Impurities\%, gave the lowest mean values were (1.81 and 1.39 for sodium $\mathrm{Na} \%$ ) and (4.65 and $4.44 \%$ for potassium $\mathrm{K} \%$ ) were resulted respectively from sowing Lola variety in both seasons. Similar result is obtained by Abou El-Maged et al (2003).

\section{II.3. Root and sugar yields (ton/fed).}

The tabulated results in Table 4 showed that the effect of varieties on root and sugar yields (ton/fed) were significant in the two seasons. Lola variety ranked the first were the highest mean values of root yield were (31 and 30 tons/fed) and sugar yield (5.27 and 4.80 tons/fed) followed by Carola variety. While, Gazella variety gave the lowest root and sugar yields/fed in both seasons., respectively. Similar results were obtained by Aly (2006) and El-Sheikh et al (2009).

Table 4. Effect of sugar beet varieties on roots growth, quality and yields at harvest

\begin{tabular}{|c|c|c|c|c|c|c|c|c|c|}
\hline \multicolumn{10}{|c|}{$2008 / 2009$ season } \\
\hline Characters & \multicolumn{3}{|c|}{ Growth traits } & \multirow{2}{*}{$\begin{array}{l}\text { Quality\% } \\
\text { Sucrose }\end{array}$} & \multicolumn{2}{|c|}{$\begin{array}{c}\text { Yields } \\
\text { (ton/fed) }\end{array}$} & \multicolumn{3}{|c|}{ Impurities $\%$} \\
\hline Varieties & $\mathrm{RL}$ & $\mathrm{RD}$ & RFW & & RY & SY & $\mathrm{a}-\mathrm{N} \%$ & $\mathrm{Na} \%$ & $\mathrm{~K} \%$ \\
\hline Gazella & 25.00 & 12.00 & 723.0 & 13.00 & 27.00 & 3.51 & 1.18 & 2.18 & 5.35 \\
\hline Carola & 31.00 & $\begin{array}{c}14 . .0 \\
0\end{array}$ & 1000 & 15.00 & 29.00 & 4.35 & 1.10 & 2.00 & 5.00 \\
\hline Lola & 28.00 & 16.00 & 1300 & 17.00 & 31.00 & 5.27 & 1.05 & 1.81 & 4.65 \\
\hline LSD at $5 \%$ & NS & NS & 0.07 & 0.31 & 0.23 & 0.05 & NS & 0.15 & 0.11 \\
\hline \multicolumn{10}{|c|}{$2009 / 2010$ season } \\
\hline Gazella & 24.00 & 11.00 & 700 & 12.00 & 26.00 & 3.12 & 0.91 & 1.79 & 5.65 \\
\hline Carola & 30.00 & 13.00 & 1100 & 14.00 & 28.00 & 3.92 & 0.81 & 1.65 & 5.10 \\
\hline Lola & 27.00 & 15.00 & 1250 & 16.00 & 30.00 & 4.80 & 0.71 & 1.39 & 4.44 \\
\hline LSD at $5 \%$ & NS & 0.65 & 0.09 & 0.36 & 0.23 & 0.08 & NS & 0.12 & 0.10 \\
\hline
\end{tabular}

Growth traits, RL and RD (root length and diameter $\mathrm{cm}$ ), RFW: root fresh weight (g/plant). Yields, RY and SY (root and sugar yields/fed). Impurities\% (N: nitrogen, Na: sodium, K: potassium). 
III. INTERACTIONS EFFECTS:

\section{1. Growth traits: Root diameter $(\mathrm{cm})$ and root fresh weight (g/plant).}

Results presented in Tables 5 and 6 showed that the interaction effect between harvesting dates and sugar beet varieties on root fresh weight $(\mathrm{g} / \mathrm{plant})$ was significant in both seasons. Harvesting Lola variety at 195 day gave the highest root fresh weight values (1300 and $1220 \mathrm{~g} /$ plant). While, root diameter was significantly affected in the $1^{\text {st }}$ season and it gave $18 \mathrm{~cm}$.

Table 5. the interaction between harvesting dates and varieties

\begin{tabular}{|c|c|c|c|c|c|}
\hline \multicolumn{2}{|c|}{ Characters } & \multicolumn{2}{|c|}{$\begin{array}{c}\text { Growth traits } \\
\text { Root diameter } \\
(\mathrm{cm})\end{array}$} & $\begin{array}{c}\text { Root fresh weight (g/plants) } \\
\text { Sucrose }\end{array}$ & \multicolumn{2}{c|}{ Root } & Sugar \\
\hline \multicolumn{7}{|c|}{$2008 / 2009$ season } \\
\hline $180 \times$ Gazella & 14.0 & 1009 & 14.0 & 27.0 & 3.78 \\
\hline $195 \times$ Gazella & 15.0 & 1272 & 16.0 & 31.0 & 4.96 \\
\hline $210 \times$ Gazella & 16.0 & 1089 & 15.0 & 29.0 & 4.35 \\
\hline $180 \times$ Carola & 16.0 & 1000 & 15.0 & 29.0 & 4.64 \\
\hline $195 \times$ Carola & 18.0 & 1210 & 17.5 & 31.0 & 5.27 \\
\hline $210 \times$ Carola & 17.0 & 1150 & 16.0 & 30.0 & 4.80 \\
\hline $180 \times$ Lola & 15.0 & 1159 & 15.0 & 28.0 & 4.06 \\
\hline $195 \times$ Lola & 18.0 & 1300 & 17.0 & 33.0 & 5.78 \\
\hline $210 \times$ Lola & 17.0 & 1275 & 0.32 & 0.59 & 0.17 \\
\hline LSD at 5\% & 0.92 & 0.08 & &
\end{tabular}

\section{III.2. Root and sugar yields (ton/fed):}

Results presented in Tables 5 and 6 indicated that the interaction effect between harvesting dates and sugar beet varieties on root and sugar yields (ton/fed) were significant in both seasons. Harvesting Lola variety at 195 days from sowing gave the highest root yield, the values were (33 and 32 tons/fed) and sugar yields were (5.78 and 5.76 tons/fed) for the $1^{\text {st }}$ and $2^{\text {nd }}$ seasons., respectively.

\section{III.3. Juice quality (sucrose $\%$ ) and impurities \% (a-N\%, $\mathrm{Na} \%$ and $\mathrm{K} \%$ ).}

Results in Table 5 and 6 pointed out that the interaction effect between harvesting dates and sugar beet varieties on sucrose $\%$ was significant in both seasons. Harvesting Lola variety at 195 days from sowing gave the highest mean values. Impurities $\%$, sodium and potassium $\%$ were decrease significant in the $2^{\text {nd }}$ season. Harvesting Lola variety at 195 days from sowing gave the lowest mean values (1.30 and $4.20 \%)$. 
Table 6. the interaction between harvesting dates and varieties

\begin{tabular}{|c|c|c|c|c|c|c|}
\hline \multirow{2}{*}{ Characters } & Growth traits & Quality\% & \multicolumn{2}{|c|}{$\begin{array}{c}\text { Yields } \\
\text { (ton/fed) }\end{array}$} & \multicolumn{2}{c|}{ Impurities } \\
\cline { 2 - 7 } & Root fresh weight (g/plant) & Sucrose & Root & Sugar & $\begin{array}{c}\text { Sodium } \\
\%\end{array}$ & $\begin{array}{c}\text { Potassium } \\
\%\end{array}$ \\
\hline \multicolumn{7}{|c|}{$2009 / 2010$} \\
\hline $180 \times$ Gazella & 929 & 15.0 & 28.0 & 4.20 & 1.97 & 5.80 \\
\hline $195 \times$ Gazella & 1199 & 17.0 & 31.0 & 5.27 & 1.49 & 4.70 \\
\hline $210 \times$ Gazella & 1008 & 16.0 & 30.0 & 4.80 & 1.80 & 5.00 \\
\hline $180 \times$ Carola & 900 & 14.0 & 27.0 & 3.78 & 1.65 & 5.80 \\
\hline $195 \times$ Carola & 1189 & 16.5 & 31.0 & 5.12 & 1.40 & 4.60 \\
\hline $210 \times$ Carola & 1075 & 16.0 & 28.0 & 4.48 & 1.50 & 5.10 \\
\hline $180 \times$ Lola & 915 & 16.0 & 29.0 & 4.64 & 1.70 & 5.10 \\
\hline $195 \times$ Lola & 1220 & 18.0 & 32.0 & 5.76 & 1.30 & 4.20 \\
\hline $210 \times$ Lola & 1061 & 17.0 & 30.0 & 5.10 & 1.50 & 4.90 \\
\hline LSD 5\% & 0.06 & 0.39 & 0.10 & 0.15 & 0.18 & 0.28 \\
\hline
\end{tabular}

\section{CORRELATION STUDY:}

Results in Table 7 showed that in the $1^{\text {st }}$ season 2008/2009, matrices of simple correlation coefficients between studied sugar beet characters. Sugar yield ton/fed was strongly positive correlated with root yield ton/fed and sucrose\%. The correlation coefficient values between sugar yield ton/fed and these characters were 0.749 and 0.381 . these results indicated that sugar yield was highly influenced with root yield and sucrose $\%$. Negative correlation was occurred between root yield ton/fed with sucrose $\%$. The values for these relationship were 0.326 . Also, in the $2^{\text {nd }}$ season $2009 / 2010$, the same trend presented in the $1^{\text {st }}$ season $2008 / 2009$. These results were accordance with those reported by Dewy and Lu (1959).

Table 7. simple correlation matrix between some variables

\begin{tabular}{|c|c|c|c|}
\hline \multicolumn{5}{|c|}{$20008 / 2009$} \\
\hline Variable & Sugar yield ton/fed & Root yield ton/fed & Sucrose \% \\
\hline Sugar yield ton/fed & - & - & - \\
\hline Root yield ton/fed & $0.7492 * *$ & - & - \\
\hline Sucrose \% & $0.3808^{*}$ & $-0.3258 *$ & - \\
\hline \multicolumn{4}{|c|}{$2009 / 2010$} \\
\hline Sugar yield ton/fed & - & - & - \\
\hline Root yield ton/fed & $0.7808^{* *}$ & - & - \\
\hline Sucrose \% & $0.4814 *$ & -0.1711 & \\
\hline
\end{tabular}

Correlation coefficiens at the 0.05 and 0.01 levels of significance. 


\section{REFERENCES}

1. Abo-El Magd, B.M., M.F. Ebraheim and KH.A. Aboushady. 2003. Some chemical and technological characteristics by planting methods and different harvesting dates. J. Agric. Sci., Mansoura Univ., 28 (7): 5115-5128.

2. Aly, E.F. 2006. Effect of environmental conditions on productivity and quality of some sugar beet varieties. Ph. D. Thesis. Fac. of Agric. Benha Univ. Egypt.

3. Association of Official Agricultural Chemist. 2005. Official methods of analysis pupl. by the AOAC Box 540, Washington.

4. Azzazy, N.B., N.M.S. Shalaby and A.M. Abd El-Razek. 2007. Effect of planting density and days to harvest on yield and quality of some sugar beet varieties under Fayoum condition. Egypt J. Appl. Sci., 22 (12A):101-14.

5. CCSC 2010. Sugar Crops Council. Ann. Report, Ministry of Agric., Egypt. (In Arabic).

6. Cook, D.A. and R.K. Scott. 1993. The Sugar Beet Crops. Scientific. Practice. Publ. by Chapman and Hall, London.

7. Dewy, D.R. and K.H. Lu. 1959. A correlation and path coefficients analysis of componets of crested wheat grass seed production. Agron. J. 51: 515.

8. El-Sheikh, S.R.E., K.A.M. Khaled and S.A.A.M. Enan. 2009. Evaluation of some sugar beet varieties under three harvesting dates. J. Agric. Sci. Mansoura Univ., 34 (3): 1559-1567.

9. Enan, S.A.A.M., S.R.E. El-Sheikh and K.A.M. Khaled. 2009. Evaluation of some sugar beet varieties under different levels of $\mathrm{N}$ and Mo fertilization. J. Biol. Chem. Environ. Sci., 4 (1): 345-362.

10. Le-Docte, A. 1927. Commercial determinations of sugar in the beet root using the sacks. Le-Docte process. Int. Sugar. J. 29: 488-492.

11. Mahmoud, S.A., B. Hassanin, I.H. El-Geddawy and D.T.A. Mosa. 2008. Effect of sowing and harvesting dates on yield and quality of some sugar beet varieties. Proc. Inter. Conf. (IS 2008), Al-Arish, Egypt. Sep. 11-14 pp 22-29.

12. Osman, A.M.H., G.S. El-Sayed, M.S.H. Osman and K.S. El-Sogheir. 2003. Soil application of some microelements with relation to yield and quality of sugar beet varieties. Ann. of Agric. Sc., Moshtohor, 41 (3): 1071-1088.

13. Page, A.L. 1982. "Methods of Soil Analysis". Chemical and Microbiological Properties. $2^{\text {nd }}$ Ed., Agron. 9, Am. Soc. Agron. Inc. Publ. Madison, Wis, USA.

14. Snedecor, G.W. and W.G. Cochran. 1981. Statistical Methods. Seventh Ed. Iowa State Univ. Press, Ames, Iowa, USA.

15. Steel, RG.D. and J.H. Torrie. 1980. Principles and procedures of statistics. Mc Grow-Hill Book Co. Inc., New York. 


\section{تقييم بعض اصناف بنجر السكر وتاثرها بمواعيد الحصاد فى الار اضى الجديدة المستصلحة}

ناصر محمد السيد شلبى ، عادل محمود حسن عثمان ، اثرف حنفى سيد احمد اللبودى

$$
\text { معطج بحوث الدحاصيل السكرية - مركز البحوث الزراعبة - جيزة - مصر }
$$

اقيمت تجربتان حقليتان فى قرية كفر الحمام بمحافظة الثرقية خلال موسمى الزر اعة

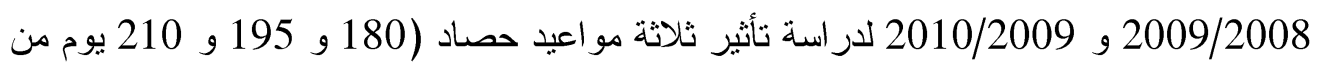
الزر اعة) على ثلاثة أصناف من بنجر السكر (جازبلا و كارولا ولو لا) للحصول على أعلى محصول تلائل

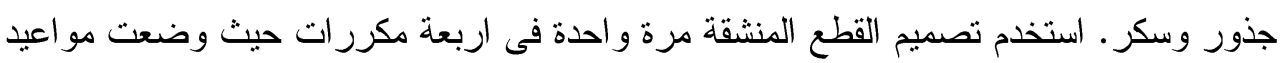

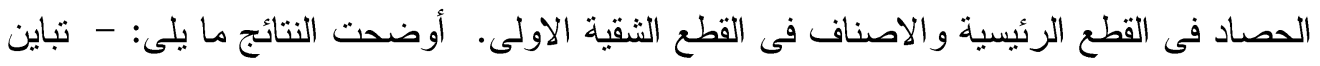

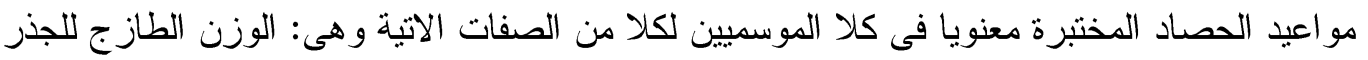

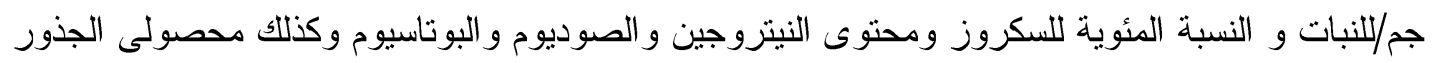
و السكر طن/فدان. وقد حقق ميعاد الحصكا19 يوم اعلى محصول وجودة. - بينما اختلفت الاصناف معنويا فى الصفات التالية قطر الساق فى الموسم الثانى فقط وكانت معنوية فى الموسميين لكلا من وزن الجذر الطازج و النسبة المئوية للسكروز وكذلك محتوى الصوديوم و البوتاسيوم ومحصولى الجذور و السكر طن/فدان وقد نتفوق لصنف لو لا على الصنفين كارو لا وجازيلا.اوضحت النتائج ان هناك زيادة معنوية للتفاعل بين

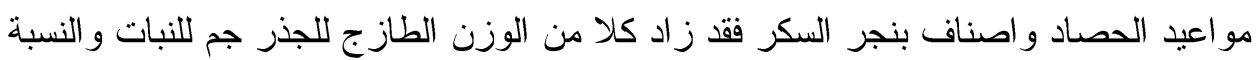
المئوية للسكروز ومحصولى الجذور و السكر طن/فدان فى كلا الموسمبين وكانت عمعنوية لمحتوى لون لهن الصوديوم و البوتاسيوم فى الجذور فى الموسم الثانى فقط وكانت معنوية لقطر الجذر فى فئ الموسم

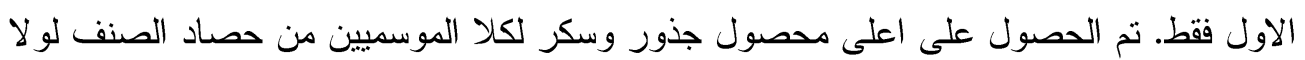
عند 195 يوم من الزر اعة وكانت النتائج كالتالى (33 و 32 طن جذور /فدان) ثم ( 5.78 و 5.76 طن سكر/فدان) على التوالى. - ووجد ارتباط معنوى موجب بين صفة محصول السكر وكلا من

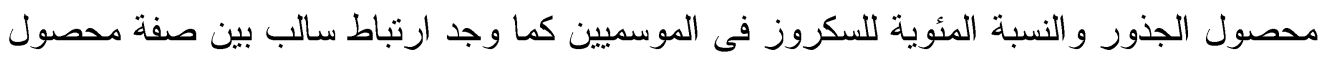
الجذور و النسبة المئوية للسكروز فى كلا الموسميين. تحت ظروف محافظة الثرقية يوصى هذا فئسئ البحث بحصاد الاصناف تحت الدراسة عند 195 يوم من الزر اعة للحصول على اعلى محصول 